\title{
The Intestinal Fate of Citrus Flavanones and Their Effects on Gastrointestinal Health
}

\author{
Yala Stevens ${ }^{1,2}, * \mathbb{B}$, Evelien Van Rymenant ${ }^{3}$, Charlotte Grootaert ${ }^{3}$, John Van Camp ${ }^{3}$, \\ Sam Possemiers ${ }^{4}$, Adrian Masclee ${ }^{1}$ and Daisy Jonkers ${ }^{1}$ \\ 1 Department of Internal Medicine, Division of Gastroenterology-Hepatology, School of Nutrition and \\ Translational Research in Metabolism (NUTRIM), Maastricht University, P.O. Box 616, \\ 6200 MD Maastricht, The Netherlands \\ 2 BioActor BV, Gaetano Martinolaan 85, 6229 GS Maastricht, The Netherlands \\ 3 Department of Food Technology, Safety and Health, Research Group Food Chemistry and Human Nutrition, \\ Ghent University, Coupure Links 653, 9000 Ghent, Belgium \\ 4 ProDigest BVBA, Technologiepark 82, 9052 Ghent, Belgium \\ * Correspondence: yala.stevens@maastrichtuniversity.nl
}

Received: 11 June 2019; Accepted: 24 June 2019; Published: 27 June 2019

\begin{abstract}
Citrus flavanones, with hesperidin and naringin as the most abundant representatives, have various beneficial effects, including anti-oxidative and anti-inflammatory activities. Evidence also indicates that they may impact the intestinal microbiome and are metabolized by the microbiota as well, thereby affecting their bioavailability. In this review, we provide an overview on the current evidence on the intestinal fate of hesperidin and naringin, their interaction with the gut microbiota, and their effects on intestinal barrier function and intestinal inflammation. These topics will be discussed as they may contribute to gastrointestinal health in various diseases. Evidence shows that hesperidin and naringin are metabolized by intestinal bacteria, mainly in the (proximal) colon, resulting in the formation of their aglycones hesperetin and naringenin and various smaller phenolics. Studies have also shown that citrus flavanones and their metabolites are able to influence the microbiota composition and activity and exert beneficial effects on intestinal barrier function and gastrointestinal inflammation. Although the exact underlying mechanisms of action are not completely clear and more research in human subjects is needed, evidence so far suggests that citrus flavanones as well as their metabolites have the potential to contribute to improved gastrointestinal function and health.
\end{abstract}

Keywords: citrus flavanones; intestinal microbiota; intestinal barrier function; intestinal inflammation; gastrointestinal health

\section{Introduction}

Polyphenols are naturally occurring secondary metabolites found in plants, where they play an important role in the plant's defense systems by providing protection against, e.g., pathogens, insects, and UV radiation. Different classes of polyphenols can be identified, of which flavonoids are the largest and most studied group. Flavonoids have a widespread presence in edible plants and are a prominent part of the human diet. They can be classified based on their chemical structure into a variety of subclasses, such as flavanones, flavones, isoflavones, flavans (flavanols), anthocyanins, and flavonols. In Europe at the population level, a median daily flavonoid intake of 335.0 and $332.2 \mathrm{mg}$ was found in men and women, respectively, of which about $5 \%$ could be attributed to flavanone consumption [1]. In contrast to other flavonoids that are present in a wide range of foods such as fruits, vegetables, cereals, legumes, and beverages like tea and red wine, the presence of flavanones in the human diet is mainly restricted to citrus fruits, and to a lower extent to tomatoes and aromatic 
herbs like mint [2]. Despite the fact that their presence is limited, flavanones contribute significantly to the dietary flavonoid intake because of the widespread consumption of citrus fruits and juices $[3,4]$. The main flavanone glycosides present in citrus fruits are hesperidin and naringin. Hesperidin is the principal flavanone in sweet oranges, while naringin is the most abundant flavanone in grapefruit and is primarily responsible for its distinct bitter taste [5]. Commercial sweet orange juice contains between 4.5 and $76.3 \mathrm{mg} / 100 \mathrm{~mL}$ hesperidin with an average of $37.5 \mathrm{mg} / 100 \mathrm{~mL}$, whereas naringin concentrations in commercial grapefruit juice range between 4.8 and $119.7 \mathrm{mg} / 100 \mathrm{~mL}$ with an average of $43.5 \mathrm{mg} / 100 \mathrm{~mL}$ [6]. Overall, the average daily population intake of flavanones in Europe was found to be $25.7 \pm 27.1 \mathrm{mg}$, being most often consumed as fruits $(72.0 \%)$, juices $(17.2 \%)$, wine $(5.4 \%)$, and soft drinks (1.7\%) [7].

The consumption of citrus flavanones has repeatedly been associated with a lower risk of degenerative diseases such as cardiovascular diseases and cancers [8-13]. This potentially protective effect has been related to the various properties of these compounds, which include anti-oxidative and anti-inflammatory activities [14-16]. Additionally, recent evidence has indicated that citrus flavanones could modulate the microbiota composition and activity by inhibiting pathogenic bacteria and selectively stimulating the growth of beneficial bacteria $[17,18]$. As inflammation, oxidative stress, and intestinal microbiota perturbations are involved in several gastrointestinal (GI) as well as metabolic diseases, consumption of citrus flavanones may contribute to the maintenance of intestinal homeostasis and may improve GI health. The intestinal microbiota has many functions that are important for host health. These include protection against pathogen colonization, maintenance of intestinal barrier function, for example, by secretion of mucus and regulation of the junctional complex, interaction with the host immune system, and its large metabolic capacity [19]. During normal intestinal homeostasis, the balance between inhibiting invading pathogens and tolerance to commensal microbes is tightly regulated $[20,21]$. However, a disturbed barrier function and/or reduced tolerance, may facilitate intestinal inflammation [22,23]. As part of the inflammatory response, reactive oxygen species and reactive nitrogen species are produced, resulting in enhanced exposure to oxidative stress [24].

Because of their putative mechanistic effects, citrus flavanones may be of interest in the prevention and/or treatment of various diseases. Most studies use extracts or purified bioactive compounds to study the effects of citrus flavanones. Their effects however, may be influenced by processes taking place in the GI tract such as bacterial metabolism and absorption. Therefore, in this review, we will provide an overview of the current evidence on the intestinal fate of citrus flavanones, including their interaction with the intestinal microbiota as well as their effects on factors contributing to GI health.

\section{Intestinal Fate and Bioavailability}

The basic chemical structure of flavonoids consists of 15 carbon atoms, two aromatic rings (A and B), and a pyran ring (C) (Figure 1). Hesperidin and naringin are both flavanone glycosides. Their aglycones hesperetin and naringenin are attached to disaccharides consisting of glucose and rhamnose at the seventh-carbon position, with rhamnose as the terminal sugar (Figure 2a,b). Beneficial effects of citrus flavanones (e.g., radical scavenging and anti-inflammatory activity and modulation of microbiota) are considered to be related to their biochemical structure, such as the number and specific position of hydroxyl groups on the A and B ring and the presence of the sugar moiety [16,25-27]. 


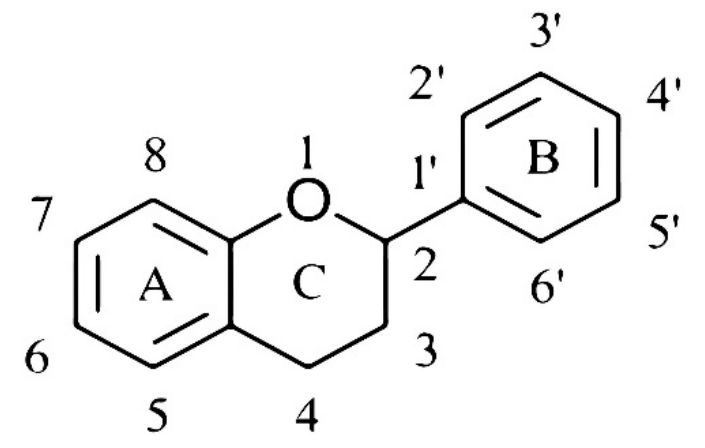

Figure 1. Basic chemical structure of flavonoids.

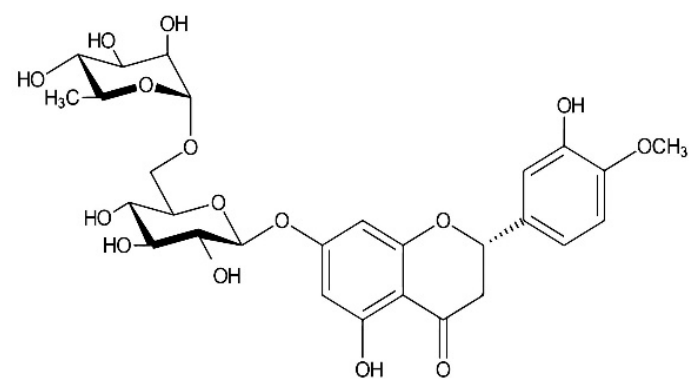

(a) hesperetin-7-O-rutinoside

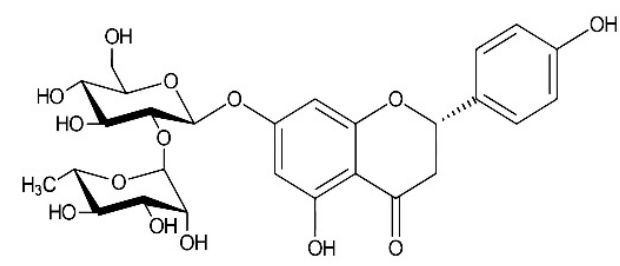

(b) naringenin-7-O-neohesperidoside

Figure 2. Chemical structure of hesperidin (a) and naringin (b).

The ability of citrus flavanones to exert beneficial effects strongly depends on their bioavailability, which can be affected by the structure of the compound, the food matrix, and host factors [28]. The intestinal metabolism of citrus flavanones is mainly determined by their degree of conjugation to sugar moieties [29-31] and the removal of these by intestinal bacteria [29]. Citrus flavanones such as hesperidin and naringin are considered to be largely resistant to enzymatic breakdown in the stomach and small intestine and, thereby, mainly reach the colon intact. Here, hesperidin and naringin are exposed to $\alpha$-rhamnosidases secreted by the gut microbiota, which remove the rhamnose moiety followed by the removal of glucose by $\beta$-glucosidases [31-33]. Although the majority is converted in the colon, some breakdown can already take place in the distal part of the small intestine [34]. Upon release, the aglycones hesperetin and naringenin are absorbed through the intestinal epithelium by means of passive diffusion and proton-coupled active transport, or are further metabolized into phenolic acids and simple phenolics by C-ring cleavage, demethylation and dehydroxylation by bacterial enzymes [31,35-38]. Hence, the bioavailable fraction in the intestine upon citrus flavanone consumption is likely to consist of a mix of hesperetin, naringenin, and phenolic metabolites.

\subsection{Intestinal Metabolism: In Vitro Evidence}

Because of difficulties in sampling the small intestine and proximal colon, there are only limited data available on the biotransformation of citrus flavanones in the GI tract in vivo. Data from studies measuring fecal excretion levels show that these compounds have been metabolized extensively within the intestine, resulting in the formation of the aglycone forms and smaller phenolics [35,39]. Data from in vitro studies using various GI digestion models have provided additional information. In vitro digestion of hesperidin, naringin, and their aglycones has been carried out either in batch-like settings using incubations with fecal slurries or isolated bacteria [37,40,41], or in more comprehensive models, such as the TNO in vitro model of the colon (TIM-2) and the simulator of the human intestinal microbial ecosystem (SHIME) [42,43]. These in vitro studies, listed in Table 1, show quite consistently that during colonic microbial fermentation, hesperidin and naringin are first metabolized into their aglycones hesperetin and naringenin and subsequently into various phenolics, including 
dihydrocaffeic acid, isoferulic acid, 4-hydroxyphenylacetic acid, dihydroferulic acid, ferulic acid, resorcinol, phloroglucinol, 2,4-dihydroxyphenylacetic acid, 4-hydroxybenzoic acid, phloretic acid, phloroglucinic acid, hydrocinnamic acid, 3-(3'-hydroxyphenyl)propionic acid, protocatechuic acid, and hippuric acid. More information about the metabolism of citrus flavanones, including an overview of the proposed pathways, can also be found in a review by Kay et al. [44].

In addition to the type of metabolites formed, a recent study by Van Rymenant et al. provided information about the location of citrus flavanone metabolism. Using a digestion model comprising compartments representing the ascending, transverse, and descending colon (SHIME) inoculated with a fecal sample from a healthy volunteer, the metabolites formed upon hesperidin conversion were found at the highest concentrations in the compartments representing the ascending and transverse colon, while lower concentrations were measured in the descending colon [42]. These in vitro results suggest that microbial metabolism predominantly takes place in the more proximal parts of the colon. It should be noted that in vivo absorption mechanisms are lacking in these models. Furthermore, several of these studies used single or pooled samples for inoculation. Chen et al., investigating the in vitro biotransformation of naringin by intestinal bacteria from healthy human volunteers using labeled naringin, found that (intermediate) metabolites differed between subjects [45].

\subsection{Bioavailability in Humans}

Human studies performing analyses in plasma, urine, and/or feces also showed the formation of their aglycone forms as well as many smaller phenolic metabolites after the consumption of citrus flavanones (see also Table 2) [46-50]. These data indicate that citrus flavanones, like many other polyphenols, undergo extensive metabolism in vivo by the intestinal microbiota. Several of the metabolites identified in the in vitro simulations mentioned previously, were also found in these in vivo samples, suggesting that in vitro simulations have the capacity to mimic in vivo metabolism. It should be noted however that variations in flavanone metabolism can be found between individual subjects or donors both in vitro and in vivo, indicating that more research is needed. In addition, as most of these studies were performed in healthy volunteers or with fecal donations of healthy volunteers, it is unclear how disease states, dietary factors, and medication use may impact these findings. Although data are scarce, a few studies investigated the effects of the food matrix or medication use on the bioavailability of citrus flavanones. For example, the effects of the solubility of flavanones in orange juice and the ingestion of yoghurt together with orange juice on excretion levels of metabolites have been reported [46,51]. 
Table 1. Nonexclusive listing of in vitro studies investigating the colonic metabolism of citrus flavanones.

\begin{tabular}{|c|c|c|c|c|}
\hline $\begin{array}{c}\text { In Vitro Model System } \\
\text { [Ref.] }\end{array}$ & $\begin{array}{l}\text { Sampling Time } \\
\text { (Extra Sampling) }\end{array}$ & Treatment (Dosage) & Metabolites Formed & Comments \\
\hline $\begin{array}{l}\text { Batch incubation, fecal } \\
\text { samples from four healthy } \\
\text { volunteers [37] }\end{array}$ & $\begin{array}{l}24 \mathrm{~h}(1 \mathrm{~h}, 2 \mathrm{~h}, 4 \mathrm{~h}, 6 \\
\mathrm{h}, 8 \mathrm{~h}, 24 \mathrm{~h})\end{array}$ & $\begin{array}{l}\text { Hesperetin }(50 \mu \mathrm{mol} \text { in } 50 \mathrm{~mL}) \\
\text { Naringenin }(50 \mu \mathrm{mol} \text { in } 50 \mathrm{~mL})\end{array}$ & $\begin{array}{l}\text { Isoferulic acid, dihydrocaffeic acid, hydrocinnamic acid, } \\
\text { 3-(3'-hydroxyphenyl)propionic acid, phloretic acid, } \\
\text { 4-hydroxyphenylacetic acid } \\
\text { Phloretic acid, hydrocinnamic acid, 4-hydroxyphenylacetic acid }\end{array}$ & $\begin{array}{l}\text { Metabolite concentrations vary } \\
\text { between time points and donors }\end{array}$ \\
\hline $\begin{array}{l}\text { Batch incubation, bacteria } \\
\text { isolated from fresh human } \\
\text { fecal samples [40] }\end{array}$ & $12 \mathrm{~h}$ & $\begin{array}{l}\text { Hesperidin ( } 5 \mathrm{mg} \text { in } 50 \mathrm{~mL}) \\
\text { Naringin }(5 \mathrm{mg} \text { in } 50 \mathrm{~mL})\end{array}$ & $\begin{array}{l}\text { Hesperetin, resorcinol, phloroglucinol, 2,4-dihydroxyphenylacetic acid } \\
\text { Naringenin, 4-hydroxybenzoic acid, phloroglucinol, phloroglucinic acid, } \\
\text { 4-hydroxyphenylacetic acid }\end{array}$ & \\
\hline $\begin{array}{l}\text { Batch incubation, probiotic } \\
\text { bacteria (Bifidobacterium } \\
\text { longum R0175 and } \\
\text { Lactobacillus rhamnosus } \\
\text { subsp. rhamnosus NCTC } \\
\text { 10302) [41] }\end{array}$ & $\begin{array}{l}48 \mathrm{~h}(12 \mathrm{~h}, 24 \mathrm{~h}, 36 \\
\mathrm{h}, 48 \mathrm{~h})\end{array}$ & $\begin{array}{l}\text { Hesperidin }(410 \mathrm{nmol} \text { in } 10 \mathrm{~mL}) \\
\text { Naringenin }(430 \mathrm{nmol} \text { in } 10 \mathrm{~mL}) \\
\text { Hesperetin }(820 \mathrm{nmol} \text { in } 10 \mathrm{~mL}) \\
\text { Naringenin }(920 \mathrm{nmol} \text { in } 10 \mathrm{~mL})\end{array}$ & $\begin{array}{l}\text { Isoferulic acid, dihydrocaffeic acid, 3-(3'-hydroxyphenyl)propionic acid, } \\
\text { hydrocinnamic acid } \\
\text { Phloretic acid, hydrocinnamic acid }\end{array}$ & $\begin{array}{l}\text { Metabolite concentrations vary } \\
\text { between time points and } \\
\text { bacteria }\end{array}$ \\
\hline $\begin{array}{l}\text { SHIME, fecal sample from } \\
\text { one healthy volunteer [ } 42]\end{array}$ & $\begin{array}{l}3 \text { weeks ( } 1 \text { wk, } 2 \\
\text { wks, } 3 \text { wks) }\end{array}$ & Hesperidin (500 mg) & $\begin{array}{l}\text { Hesperetin, dihydrocaffeic acid, isoferulic acid, 4-hydroxyphenylacetic } \\
\text { acid, dihydroferulic acid, ferulic acid, protocatechuic acid, vanillic acid, } \\
\text { caffeic acid }\end{array}$ & \\
\hline $\begin{array}{l}\text { TIM-2, fecal samples from } \\
10 \text { healthy volunteers } \\
\text { (pooled) [43] }\end{array}$ & $\begin{array}{l}28 \mathrm{~h}(0 \mathrm{~h}, 4 \mathrm{~h}, 8 \mathrm{~h}, \\
12 \mathrm{~h}, 16 \mathrm{~h}, 24 \mathrm{~h}, \\
\text { and } 28 \mathrm{~h})\end{array}$ & $\begin{array}{l}\text { Citrus + rutin supplement }(284 \\
\text { mg rutin, } 430 \mathrm{mg} \text { naringin, } 88 \\
\text { mg hesperidin, } 4.4 \mathrm{mg} \\
\text { eriodictyol). }\end{array}$ & $\begin{array}{l}\text { Phloretic acid, isoferulic acid, dihydroferulic acid, dihydrocaffeic acid, } \\
\text { homovanillic acid, 3-hydroxyphenylacetic acid, 4-hydroxyphenylacetic } \\
\text { acid, 2,4-dihydroxyphenylacetic acid, 3,4-dihydroxyphenylacetic acid, } \\
\text { hippuric acid, resorcinol, phloroglucinol }\end{array}$ & \\
\hline $\begin{array}{l}\text { Batch incubation, fecal } \\
\text { samples from } 30 \text { healthy } \\
\text { volunteers [45] }\end{array}$ & $\begin{array}{l}24 \mathrm{~h}(4 \mathrm{~h}, 8 \mathrm{~h}, 12 \mathrm{~h}, \\
24 \mathrm{~h})\end{array}$ & $\begin{array}{l}{\left[2^{\prime}, 3^{\prime}, 5^{\prime}, 6^{\prime}-\mathrm{D} 4\right] \text { naringin }(10 \mu \mathrm{L}} \\
(20 \mathrm{mg} / \mathrm{mL}) \text { in } 990 \mu \mathrm{L})\end{array}$ & 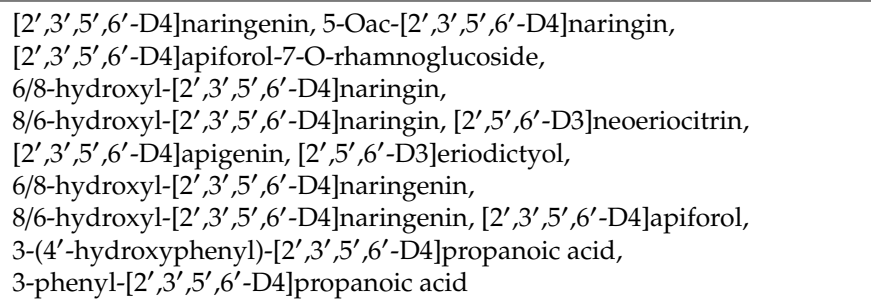 & $\begin{array}{l}\text { Metabolism varies between } \\
\text { donors }\end{array}$ \\
\hline
\end{tabular}

Various metabolites were found after in vitro colonic fermentation of citrus flavanones. A number of metabolites were formed in several different studies, but differences between studies have been observed, which might be due to differences in the methods and donors used. SHIIME, simulator of the human intestinal microbial ecosystem. TIM-2, TNO in vitro model of the colon. 
Table 2. Nonexclusive listing of studies investigating the metabolism and bioavailability of citrus flavanones in human subjects.

\begin{tabular}{|c|c|c|c|c|}
\hline $\begin{array}{c}\text { Population (Design) } \\
\text { [Ref.] }\end{array}$ & $\begin{array}{c}\text { Treatment } \\
\text { (Dosage/Flavanone } \\
\text { Concentration) }\end{array}$ & $\begin{array}{l}\text { Sample and Sampling } \\
\text { Time (Extra Sampling) }\end{array}$ & Metabolites Formed & Comments \\
\hline $\begin{array}{l}\text { Healthy subjects, } n=7 \\
\text { (pre- and post-test) }[46]\end{array}$ & $320 \mathrm{mg}$ naringin & $\begin{array}{l}72 \mathrm{~h} \text { urine }(0-4 \mathrm{~h}, 4-8 \mathrm{~h}, \\
8-12 \mathrm{~h}, 12-24 \mathrm{~h}, 24-36 \mathrm{~h}, \\
36-48 \mathrm{~h}, 48-60 \mathrm{~h}, 60-72 \\
\mathrm{~h}), 72 \mathrm{~h} \text { feces }\end{array}$ & $\begin{array}{l}\text { Urine and feces: 4-hydroxybenzoic acid, 4-hydroxyhippuric acid, hippuric acid, } \\
\text { phoretic acid, phloretic acid sulfate, naringin, naringenin, naringenin diglucuronide } \\
\text { Urine: naringenin diglucuronide, naringenin glucoside glucuronide, naringenin } \\
\text { glucoside sulfate, naringenin glucuronide sulfate, naringin glucuronide, naringenin } \\
\text { sulfate, hydroxylated naringenin glucuronide, naringenin glucuronide, naringenin } \\
\text { glucuronide dimer, hydroxylated naringenin sulfate }\end{array}$ & $\begin{array}{l}\text { Excretion of metabolites } \\
\text { varied between } \\
\text { individuals }\end{array}$ \\
\hline $\begin{array}{l}\text { Healthy volunteers, } n=12 \\
\text { (pre- and post-test) }[47]\end{array}$ & $\begin{array}{l}\text { Orange juice }(500 \mathrm{~mL} / 398 \\
\mu \mathrm{mol} \text { (poly)phenols, of } \\
\text { which } 246 \mu \mathrm{mol} \text { was } \\
\text { hesperidin) }\end{array}$ & $\begin{array}{l}24 \mathrm{~h} \text { plasma }(0 \mathrm{~h}, 1 \mathrm{~h}, 2 \mathrm{~h}, \\
3 \mathrm{~h}, 4 \mathrm{~h}, 5 \mathrm{~h}, 6 \mathrm{~h}, 7 \mathrm{~h}, 8 \mathrm{~h}, \\
24 \mathrm{~h})\end{array}$ & 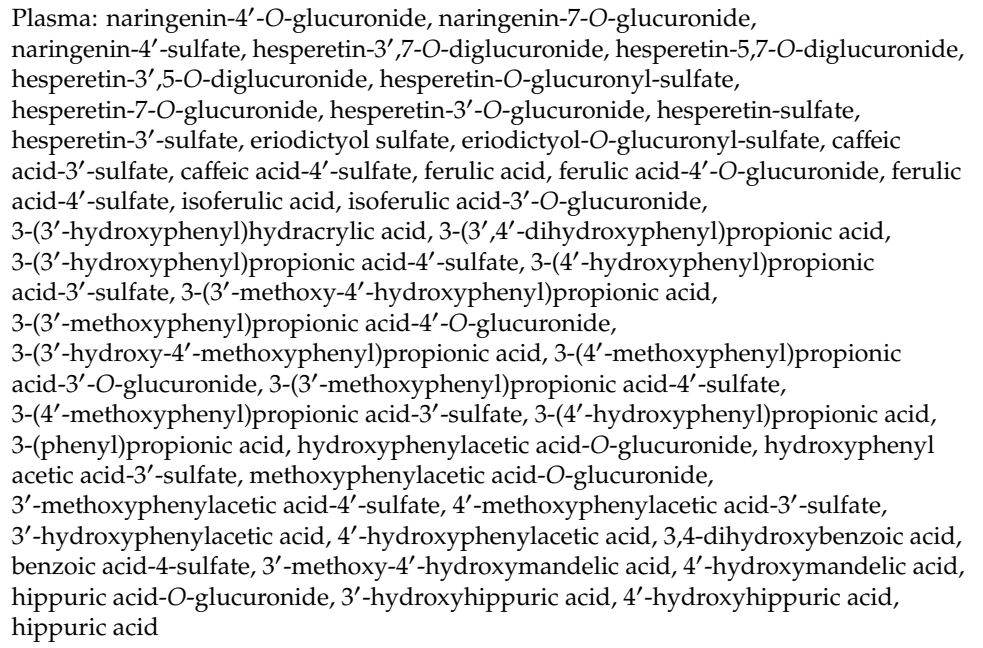 & \\
\hline
\end{tabular}


Table 2. Cont.

\begin{tabular}{|c|c|c|c|c|}
\hline $\begin{array}{l}\text { Population (Design) } \\
\text { [Ref.] }\end{array}$ & $\begin{array}{c}\text { Treatment } \\
\text { (Dosage/Flavanone } \\
\text { Concentration) }\end{array}$ & $\begin{array}{l}\text { Sample and Sampling } \\
\text { Time (Extra Sampling) }\end{array}$ & Metabolites Formed & Comments \\
\hline & & $\begin{array}{l}24 \mathrm{~h} \text { urine (baseline, } 0-5 \\
\mathrm{~h}, 5-8 \mathrm{~h}, 8-10 \mathrm{~h}, 10-24 \mathrm{~h} \text { ) }\end{array}$ & $\begin{array}{l}\text { Urine: same as plasma, but also naringenin-4',7-O-diglucuronide, } \\
\text { naringenin-5,7-O-diglucuronide, naringenin-4',5-O-diglucuronide, } \\
\text { naringenin-O-glucuronyl-sulfate, hesperetin-5-O-glucuronide, } \\
\text { hesperetin-O-glucosyl-sulfate, 3'-hydroxycinnamic acid, coumaric } \\
\text { acid-3'-O-glucuronide, } 4^{\prime} \text {-hydroxycinnamic acid, coumaric acid-4'-O-glucuronide, } \\
\text { coumaric acid-4'-sulfate, caffeic acid-3'-O-glucuronide, caffeic acid-4'-O-glucuronide, } \\
\text { 3-(3'-hydroxyphenyl)propionic acid-4'-O-glucuronide, 3-(phenyl)propionic } \\
\text { acid-4'-O-glucuronide, 3-(4'-hydroxyphenyl)propionic acid-3-O-glucuronide, } \\
\text { 3-(3'-hydroxyphenyl)propionic acid, 3-(phenyl)propionic acid-3'-O-glucuronide, } \\
\text { 3-(phenyl)propionic acid-4'-sulfate,3-(phenyl)propionic acid-3'-sulfate, } \\
\text { 3', } 4^{\prime} \text {-dihydroxyphenylacetic acid, hydroxyphenylacetic acid-4'-sulfate, } \\
\text { 3'-methoxy-4'-hydroxyphenylacetic acid, 3', } 4^{\prime} \text {-dimethoxyphenylacetic acid, } \\
\text { phenylacetic acid, hydroxybenzoic acid-O-glucuronide, 3-hydroxybenzoic } \\
\text { acid-4-sulfate, 4-hydroxybenzoic acid-3-sulfate, 3-methoxy-4-hydroxybenzoic acid, } \\
\text { 3-hydroxy-4-methoxybenzoic acid, 3-hydroxybenzoic acid, 4-hydroxybenzoic acid, } \\
\text { benzoic acid-3-sulfate, 1,3,5-trihydroxyphenol, 1,2,3-trihydroxyphenol, } \\
\text { 1,2-dihydroxyphenol }\end{array}$ & \\
\hline $\begin{array}{l}\text { Healthy subjects, } n=5 \\
\text { (controlled cross over) [48] }\end{array}$ & $\begin{array}{l}\text { Orange juice }(250 \mathrm{~mL} / 168 \\
\mu \text { mol hesperidin, } 12 \mu \mathrm{mol} \\
\text { narirutin) }\end{array}$ & $\begin{array}{l}24 \mathrm{~h} \text { urine }(0-2 \mathrm{~h}, 2-5 \mathrm{~h} \text {, } \\
5-10 \mathrm{~h}, 10-24 \mathrm{~h})\end{array}$ & $\begin{array}{l}\text { 3-hydroxyphenylacetic acid, 3-hydroxyphenylhydracrylic acid, dihydroferulic acid, } \\
\text { 3-methoxy-4-hydroxyphenylhydracrylic acid, 3-hydroxyhippuric acid }\end{array}$ & \\
\hline $\begin{array}{l}\text { Healthy volunteers, } n=12 \\
\text { (controlled cross over) [49] }\end{array}$ & $\begin{array}{l}\text { Pulp-enriched orange juice } \\
(250 \mathrm{~mL} / 537 \mu \text { mol } \\
\text { flavanones, of which } 329 \\
\mu \text { mol was hesperidin) }\end{array}$ & $\begin{array}{l}24 \mathrm{~h} \text { urine }(0 \mathrm{~h}, 0-2 \mathrm{~h}, \\
2-5 \mathrm{~h}, 5-10 \mathrm{~h}, 10-24 \mathrm{~h})\end{array}$ & $\begin{array}{l}\text { Hesperetin-O-diglucuronide, hesperetin- } O \text {-sulfate-O-glucuronide, } \\
\text { hesperetin-O-sulfate-O-glucoside, hesperetin-7-O-glucuronide, } \\
\text { hesperetin-3-O-glucuronide, hesperetin-3-O-sulfate, naringenin-O-diglucuronide, } \\
\text { naringenin-4'-O-glucuronide, naringenin-7-O-glucuronide, eriodictyol-O-sulfate } \\
\text { 3-(3'-hydroxy-4'-methoxyphenyl)hydracrylic acid, isoferulic acid, dihydroferulic acid, } \\
\text { 3'-hydroxyhippuric acid, 4'-hydroxyhippuric acid, 3-(3'-hydroxyphenyl)hydracrylic } \\
\text { acid, 3-methoxy-4-hydroxyphenylacetic acid, hippuric acid }\end{array}$ & $\begin{array}{l}\text { Excretion of metabolites } \\
\text { varied between } \\
\text { individuals }\end{array}$ \\
\hline $\begin{array}{l}\text { Men at moderate CVD } \\
\text { risk, } n=16 \text { (controlled } \\
\text { cross over) [50] }\end{array}$ & $\begin{array}{l}\text { Orange juice, }(767 \mathrm{~mL} / 320 \\
\text { mg hesperidin) }\end{array}$ & $5 \mathrm{~h}$ plasma & $\begin{array}{l}\text { Hesperetin-glucuronide, naringenin-7-glucuronide, hesperetin-glucuronide, } \\
\text { naringenin-glucuronide, hesperetin, naringenin } \\
\text { Hippuric acid, dihydroferulic acid, dihydroferulic acid-3-glucuronide, } \\
\text { 4-hydroxyphenylacetic acid, vanillic acid, hydroxyhippuric acid, iso/ferulic } \\
\text { acid-glucuronide, 3- hydroxyhippuric acid, isovanillic acid, 3-hydroxyphenylacetic acid, } \\
\text { vanillic acid-glucuronide, isovanillic acid-glucuronide, iso/vanillic acid-glucuronide, } \\
\text { 4-hydroxy-benzoic acid, benzoic acid-4-glucuronide }\end{array}$ & \\
\hline
\end{tabular}

differences between studies have also been observed. These differences might be due to differences in study designs and host factors, including the microbiota. CVD, cardiovascular disease. 


\section{Effects on Microbiota Composition}

The intestinal microbiota is a complex ecosystem which varies between individuals [52]. The interaction between the gut microbiota and polyphenols is considered to be bidirectional-in addition to the ability of intestinal bacteria to metabolize polyphenols, evidence has also accumulated that polyphenols may induce changes in the microbiota towards a more favorable composition and activity, including the production of short-chain fatty acids (SCFAs) in the colon. These metabolites have many known beneficial biological effects, e.g., acting as fuel for enterocytes, improving barrier function, and inhibiting inflammation $[53,54]$. Studies investigating the effect of citrus flavanones or food products derived from citrus fruit on the intestinal or fecal microbiota have mainly focused on their ability to inhibit the growth of pathogens, to increase beneficial commensal bacteria (such as Bifidobacterium and Lactobacillus species), and to stimulate the production of SCFAs.

\subsection{In Vitro Studies}

Duda-Chodak showed in vitro that both citrus flavanone aglycones, hesperetin and naringenin, inhibited the growth of different bacterial species after $24 \mathrm{~h}$ of incubation, while the parent compounds did not have such an effect. These included effects on Bacteroides galacturonicus, Enterococcus caccae, Bifidobacterium catenulatum, Ruminococcus gauvreauii, and Escherichia coli. The growth of Lactobacillus spp. was inhibited by naringenin only. Inhibitory effects were observed at concentrations of at least $250 \mu \mathrm{g} / \mathrm{mL}$ [18]. The ability of naringenin to inhibit bacterial growth was also confirmed by Parkar et al., who tested the effects on E. coli, Staphylococcus aureus, Salmonella typhimurium, and Lactobacillus rhamnosus. In this study, even lower minimum inhibitory concentrations were reported, being $62.5 \mu \mathrm{g} / \mathrm{mL}$ for S. aureus and $125 \mu \mathrm{g} / \mathrm{mL}$ for the other three strains [55]. Antibacterial activities of citrus flavanones have also been shown against vancomycin-intermediate S. aureus (VISA) at a concentration of $400 \mu \mathrm{g} / \mathrm{mL}$ for naringenin and $3200 \mu \mathrm{g} / \mathrm{mL}$ for naringin and hesperetin [56], and against Aeromonas hydrophila after $3125 \mu \mathrm{g} / \mathrm{mL}$ hesperidin treatment [57]. However, other studies failed to show the antibacterial activity of naringin, naringenin, or hesperidin against pathogens such as S. aureus and E. coli [58,59], but also found that hesperidin and naringin stimulated the growth of Bifidobacterium bifidum [60]. In addition to citrus flavanones and citrus flavanone aglycones, phenolics that might be formed as a result of colonic microbial fermentation can also influence the intestinal microbiota [55,60-63]. For example, antimicrobial effects towards E. coli have been reported for ferulic acid, isoferulic acid, 4-hydroxyphenylacetic acid, 4-hydroxybenzoic acid, vanillic acid, and caffeic acid, at concentrations ranging from approximately $100-1000 \mu \mathrm{g} / \mathrm{mL}$ depending on the specific phenolic acids and strains tested $[55,61,62]$. Interestingly, the previously mentioned study by Parkar et al. also tested the antimicrobial effect of caffeic acid and showed that naringenin was more effective at inhibiting the growth of the four different strains than caffeic acid [55]. On the other hand, Gwiazdowska et al. showed that incubation with caffeic acid and vanillic acid resulted in a stronger growth stimulation of B. bifidum than incubation with naringin and hesperidin [60].

The differences in the outcomes of the abovementioned studies may in part be due to differences in the experimental setup of these studies, such as the flavanone concentrations used. In vivo, it is possible that not the citrus flavanones themselves, but the metabolites formed as a result of microbial metabolism and cross-feeding are responsible for modulating the intestinal microbiota. Therefore, the results from studies that did not focus on single strains, but a more complete microbiota, may provide more insight into the effects that could be expected in the human GI tract.

In a study using the SHIME model, supplementation with $105 \mathrm{~mL}$ orange juice twice daily for 14 days resulted in a significant increase in Lactobacillus spp., Bifidobacterium spp., Enterococcus spp., and Clostridium spp. populations, while a decrease in enterobacteria was found. These changes in microbiota composition were accompanied by increased levels of the SCFAs acetate, butyrate, and propionate. Unfortunately, the concentration of citrus flavanones in the orange juice was not reported [17]. Changes in SCFA levels and microbiota composition were also reported in a recent study with a similar experimental setup in the SHIME model. After a three-week treatment period 
with $500 \mathrm{mg}$ citrus extract, containing $>80 \%$ hesperidin- $2 \mathrm{~S}$ and $>4 \%$ of naringin, butyrate, and total SCFAs levels, and the relative abundance of the Clostridium coccoides/Eubacterium rectale cluster were significantly increased [42]. This cluster, which is part of Clostridium cluster XIVa, includes species that are known to produce butyrate [64]. Positive effects on SCFA levels have also been shown for pure naringin at concentrations of 40 and $160 \mathrm{mg} / \mathrm{L}$, after $24 \mathrm{~h}$ of incubation in a batch-culture fermentation experiment [65].

\subsection{Animal and Human Studies}

In rats, three-week hesperetin supplementation via the diet $(16.4 \mathrm{mmol} / \mathrm{kg})$ resulted in significant increases in acetate and butyrate in the cecum. No significant effects were observed after hesperidin treatment. Similarly, hesperidin was not able to significantly affect the microbiota composition, while hesperetin administration resulted in increased proportions of Clostridium clusters IV and XVIII and a reduced proportion of Clostridium subcluster XIVa in the feces [66]. The differential effects are remarkable as hesperidin is expected to be rapidly converted into hesperetin in the proximal colon. However, in a recent rat study, oral administration of 100 and $200 \mathrm{mg} / \mathrm{kg}$ hesperidin three times a week for a period of four weeks, did result in significant changes in microbiota composition [67]. They found that hesperidin treatment, at the high dose, resulted in an increased Lactobacillus proportion, while an increased proportion of Staphylococcus and a decrease of C. coccoides/E. rectale were reported for both dosages.

The effect of hesperidin supplementation on microbiota composition and SCFAs has also been studied in humans. In a randomized, placebo-controlled trial in healthy subjects with features of metabolic syndrome, daily supplementation with $500 \mathrm{mg}$ citrus extract (with $>80 \%$ hesperidin- $2 \mathrm{~S}$ and $>4 \%$ naringin) for 12 weeks, did result in an increase in the butyrate to total SCFA ratio but not in the absolute levels of fecal SCFAs [68].

In healthy volunteers, consumption of a pasteurized orange juice with unknown flavanone content for two months resulted in a significant increase in Lactobacillus spp. and total anaerobes in fecal samples. In addition, a significant reduction in ammonium concentration and an increase in the acetate to total SCFA ratio were found compared to the baseline [69]. Daily supplementation of two orange juices with different flavanone content for seven days in healthy volunteers resulted in microbiota composition shifts, of which the most notable was an increase in the abundance of Clostridia operational taxonomic units from Mogibacteriaceae, Tissierellaceae, Veillonellaceae, Odoribacteraceae, and Ruminococcaceae families [70].

Overall, results from available in vitro, animal and human studies show that citrus flavanone treatment can affect the composition of the microbiota or growth of specific taxa. Although some findings vary, growth inhibition of Enterobacteriaceae has been demonstrated repeatedly. Unfortunately, none of the human studies on the effect of flavanones on the microbiome included analyses on fecal metabolite levels.

\section{Effects on Host Parameters Related to Gastrointestinal Health}

According to Bischoff et al., GI health comprises an effective digestion and absorption, together with a stable microbiota, effective immune status, and state of general wellbeing in the absence of GI diseases [71]. In this context, an intact intestinal barrier is considered an important factor. One of its main functions is to act as defensive barrier against intraluminal toxins, antigens, and microorganisms. Together with the intestinal microbiota and the immune system, the barrier is determined by, e.g., the mucus layer and an intact epithelial cell monolayer sealed by junctional complexes [72]. Two in vitro studies using Caco-2 cell monolayers have shown that hesperetin and naringenin were able to improve intestinal barrier function, as measured by an increase in transepithelial electrical resistance and expression levels of tight junction proteins and a decrease in fluorescein isothiocyanate (FITC)-conjugated dextran flux across the monolayer [73,74]. Emerging evidence indicates that the intestinal permeability is increased in several disorders, such as inflammatory bowel disease (IBD) [75]. 
To study the effects of citrus flavanones on barrier function and other features of IBD, chemically induced colitis models in rodents have been widely used, such as dextran sulfate sodium (DSS)-, trinitrobenzene sulfonic acid (TNBS)-, and dinitrobenzene sulfonic acid (DNBS)-induced colitis. The key findings of in vitro and in vivo studies investigating the effects of citrus flavanones on host parameters related to intestinal inflammation and barrier function are summarized in Table 3. For example, animals treated with hesperidin, hesperetin, or naringenin showed a significant improvement of chemically induced colitis symptoms and inflammatory parameters, such as pro-inflammatory cytokines and neutrophil infiltration [76-82]. Beneficial effects were also shown with regard to colonic barrier function [76,77].

Furthermore, an improved barrier function and/or decrease in intestinal inflammation have also been reported in vitro for phenolics that can be formed during flavanone metabolism, such as ferulic acid, isoferulic acid, dihydroferulic acid, dihydrocaffeic acid, hydrocinnamic acid, and phloretic acid [83-85]. Studies directly comparing the effect size versus the flavanones or aglycones are not available.

At present, data from human studies regarding the effects of citrus flavanone supplementation in IBD or other GI diseases are lacking. However, in a recent human trial in healthy subjects with features of metabolic syndrome, supplementation with a citrus extract (consisting of $>80 \%$ hesperidin- $2 \mathrm{~S}$ and $>4 \%$ naringin) for 12 weeks showed a clear tendency to reduce levels of fecal calprotectin, a commonly used biomarker of intestinal inflammation [68]. Together with the abovementioned findings from in vitro and animal studies, this underlines the relevance to further investigate the effect of citrus flavanones in individuals with GI disorders characterized by intestinal inflammation, increased intestinal permeability, and/or microbial perturbations. 
Table 3. Nonexclusive listing of studies on the effects of citrus flavanones on host parameters related to barrier function and inflammation.

\begin{tabular}{|c|c|c|c|c|}
\hline Model [Ref.] & Treatment & Treatment Duration & Dose and Administration & $\begin{array}{l}\text { Change in Main Outcomes vs. Control } \\
\text { (Relevant Concentrations) }\end{array}$ \\
\hline Caco-2 cell monolayers [73] & $\begin{array}{l}\text { Hesperetin vs. control } \\
\text { Naringenin vs. control }\end{array}$ & $24 \mathrm{~h}$ & $100 \mu \mathrm{M}$ & $\begin{array}{l}\text { Barrier function: } \uparrow \text { TEER, occludin expression, } \\
\text { claudin- } 4 \text { expression, cytoskeletal association of } \\
\text { occludin and claudin- }-1 \text {, and }-3 \\
\leftrightarrow \text { FITC-dextran flux } \\
\text { Barrier function: } \uparrow \text { TEER, occludin expression, } \\
\text { claudin- } 4 \text { expression, cytoskeletal association of } \\
\text { ZO-2, occludin and claudin- }-1,-3 \text {, and }-4 \\
\leftrightarrow \text { FITC-dextran flux }\end{array}$ \\
\hline $\begin{array}{l}\text { DSS-induced colitis in male } \\
\text { BALB/c mice [76] }\end{array}$ & Naringenin vs. control diet & 9 days & $\begin{array}{l}0.3 \% \text { of the diet, oral } \\
\text { administration }\end{array}$ & $\begin{array}{l}\text { Barrier function: } \downarrow \text { Colonic permeability, } \\
\text { claudin- } 1 \text { expression } \\
\uparrow \text { Occludin, junctional adhesion molecule-A, } \\
\text { claudin-3 expression } \\
\text { Inflammation: } \downarrow \text { DAI, colonic shortening, } \\
\text { expression of cytokines (IFN-Y, IL-6, MIP-2, } \\
\text { and IL-17A) }\end{array}$ \\
\hline $\begin{array}{l}\text { DSS-induced colitis in male } \\
\text { BALB/c mice [77] }\end{array}$ & $\begin{array}{l}\text { Naringenin vs. control diet } \\
\text { Hesperetin vs. control diet }\end{array}$ & 12 days & $\begin{array}{l}0.3 \% \text { of the diet, oral } \\
\text { administration } \\
0.3 \% \text { of the diet, oral } \\
\text { administration }\end{array}$ & $\begin{array}{l}\text { Barrier function: } \downarrow \text { Colonic permeability } \\
\uparrow \text { Occludin expression } \\
\text { Inflammation: } \downarrow \text { Weight loss, colonic damage } \\
\uparrow \text { Colon length } \\
\text { Barrier function: } \leftrightarrow \text { Colonic permeability, } \\
\text { occludin expression } \\
\text { Inflammation: } \downarrow \text { Weight loss, colonic damage } \\
\leftrightarrow \text { Colon length }\end{array}$ \\
\hline $\begin{array}{l}\text { DSS-induced colitis in male } \\
\text { BALB/c mice [78] }\end{array}$ & Hesperidin vs. control & 7 days & $\begin{array}{l}10,40,80 \mathrm{mg} / \mathrm{kg} \text {, oral } \\
\text { administration }\end{array}$ & $\begin{array}{l}\text { Inflammation: } \downarrow \text { DAI, MPO, MDA, IL-6, colonic } \\
\text { wet weight }(10,40,80 \mathrm{mg} / \mathrm{kg}) \dagger \\
\downarrow \text { Mucosal cell damage }(80 \mathrm{mg} / \mathrm{kg}) \\
\leftrightarrow \mathrm{IL}-4(10,40,80 \mathrm{mg} / \mathrm{kg})\end{array}$ \\
\hline
\end{tabular}


Table 3. Cont.

\begin{tabular}{|c|c|c|c|c|}
\hline Model [Ref.] & Treatment & Treatment Duration & Dose and Administration & $\begin{array}{l}\text { Change in Main Outcomes vs. Control } \\
\text { (Relevant Concentrations) }\end{array}$ \\
\hline $\begin{array}{l}\text { TNBS-induced colitis in } \\
\text { female Wistar rats [79] }\end{array}$ & Hesperidin vs. control & $\begin{array}{l}\text { Twice ( } 48 \mathrm{~h} \text { pre- }+48 \mathrm{~h} \\
\text { post-colitis induction) }\end{array}$ & $\begin{array}{l}2.5,5,10,25,50 \mathrm{mg} / \mathrm{kg} \text {, oral } \\
\text { administration }\end{array}$ & $\begin{array}{l}\text { Inflammation: } \downarrow \text { Colonic damage, colonic weight, } \\
\text { colonic MPO }(10,25 \mathrm{mg} / \mathrm{kg}) \\
\uparrow \text { Glutathione levels }(10,25 \mathrm{mg} / \mathrm{kg}) \text {, colonic fluid } \\
\text { absorption }(10-50 \mathrm{mg} / \mathrm{kg}) \\
\leftrightarrow \text { MDA, LTB4 }(2.5-50 \mathrm{mg} / \mathrm{kg})\end{array}$ \\
\hline $\begin{array}{l}\text { TNBS- induced colitis in male } \\
\text { Wistar rats [80] }\end{array}$ & $\begin{array}{l}\text { Orange juice vs. control } \\
\text { Grapefruit juice vs. control } \\
\text { Combination vs. control }\end{array}$ & 15 days & $\begin{array}{l}2 \mathrm{~mL} / \mathrm{kg}, 5 \mathrm{~mL} / \mathrm{kg}, 8 \mathrm{~mL} / \mathrm{kg} \text {, oral } \\
\text { administration } \\
0.1 \mathrm{~mL} / \mathrm{kg}, 0.3 \mathrm{~mL} / \mathrm{kg}, 0.5 \mathrm{~mL} / \mathrm{kg} \text {, } \\
\text { oral administration } \\
2 \mathrm{~mL} / \mathrm{kg} \text { OJ }+0.1 \mathrm{~mL} / \mathrm{kg} \mathrm{GJ} \text { (low } \\
\text { dose), } 5 \mathrm{~mL} / \mathrm{kg} \mathrm{OJ}+0.3 \mathrm{~mL} / \mathrm{kg} \\
\text { GJ (high dose), oral } \\
\text { administration }\end{array}$ & $\begin{array}{l}\text { Inflammation: } \downarrow \text { Colonic damage }(2,5,8 \mathrm{~mL} / \mathrm{kg}) \text {, } \\
\mathrm{MPO}, \mathrm{CRP}(5,8 \mathrm{~mL} / \mathrm{kg}), \mathrm{ALP}(8 \mathrm{mg} / \mathrm{kg}) \\
\uparrow \mathrm{GSH}(8 \mathrm{~mL} / \mathrm{kg}) \\
\text { Inflammation: } \downarrow \text { Colonic damage }(0.1,0.3,0.5 \\
\mathrm{mL} / \mathrm{kg}) \mathrm{MPO}, \mathrm{CRP}(0.3,0.5 \mathrm{~mL} / \mathrm{kg}), \operatorname{ALP}(0.3,0.5 \\
\mathrm{mL} / \mathrm{kg}) \\
\uparrow \mathrm{GSH}(0.3 \mathrm{~mL} / \mathrm{kg}) \\
\text { Inflammation: } \downarrow \text { Colonic damage, MPO, CRP, } \\
\mathrm{ALP}(\text { low dose, high dose) } \\
\uparrow \mathrm{GSH} \text { (high dose) }\end{array}$ \\
\hline $\begin{array}{l}\text { DNBS- induced colitis in Male } \\
\text { CD1 mice [81] }\end{array}$ & $\begin{array}{l}\text { Bergamot juice extract vs. } \\
\text { control }\end{array}$ & 4 days & $\begin{array}{l}5,10,20 \mathrm{mg} / \mathrm{kg} \text {, oral } \\
\text { administration }\end{array}$ & $\begin{array}{l}\text { Inflammation: } \downarrow \text { Colonic damage, weight loss, } \\
\text { MPO, TNF- } \alpha, \text { IL- } 1 \beta, \text { ICAM-1, p-selectin, } \\
\text { nitrotyrosine, PAR, nuclear NF-kB translocation, } \\
\text { p-JNK activation }(20 \mathrm{mg} / \mathrm{kg}) \\
\uparrow \text { Colon length }(20 \mathrm{mg} / \mathrm{kg})\end{array}$ \\
\hline $\begin{array}{l}\text { LPS-challenged broiler } \\
\text { chickens [82] }\end{array}$ & Hesperidin vs. control diet & 42 days & $\begin{array}{l}20 \mathrm{mg} / \mathrm{kg} \text { diet, oral } \\
\text { administration }\end{array}$ & $\begin{array}{l}\text { Inflammation: } \uparrow \text { Phagocytic index, villus length, } \\
\text { villus width, villus length/crypt depth } \\
\downarrow \text { Crypt depth } \\
\leftrightarrow \text { Body weight gain, feed intake feed conversion } \\
\text { ratio }\end{array}$ \\
\hline $\begin{array}{l}\text { Human subjects with features } \\
\text { of metabolic syndrome [68] }\end{array}$ & $\begin{array}{l}\text { Citrus extract ( }>80 \% \\
\text { hesperidin-2S and }<4 \% \text { of } \\
\text { naringin) vs. placebo }\end{array}$ & 12 weeks & $500 \mathrm{mg}$, oral administration & Inflammation: $\leftrightarrow$ Calprotectin \\
\hline
\end{tabular}




\section{Conclusions}

Following oral ingestion, citrus flavanones reach the distal part of the small intestine and the colon almost completely intact, where they interact with the microbiota. Evidence shows that citrus flavanones are extensively metabolized by intestinal bacteria resulting first in the formation of the aglycones hesperetin and naringenin and subsequently in the formation of various smaller phenolics. The microbiota composition and activity is highly variable between individuals, which can contribute to differences in metabolites formed and potential effects $[30,86,87]$. This can further be influenced by variations in dietary intake. Citrus flavanones and their metabolites, in turn, can also impact the microbiota composition and activity. For example, growth inhibition of Enterobacteriaceae has been reported. Beneficial effects of citrus flavanones on parameters such as GI inflammation and intestinal barrier function have repeatedly been reported, suggesting that intake of citrus flavanones can contribute to improved GI functioning and health. Based on the current evidence, this is likely a combined effect of the original compounds, their metabolites, and an interaction with the intestinal microbiome. Most of the currently available evidence is derived from in vitro and animal studies. Therefore, more research focusing on bioavailability and on effects in human subjects may help to improve our understanding of the effects of citrus flavanones in the human gut.

Author Contributions: Conceptualization, Y.S., S.P., and D.J.; writing-original draft preparation, Y.S. and E.V.R.; writing-review and editing, Y.S., E.V.R., C.G., J.V.C., S.P., A.M., and D.J.; supervision, D.J.

Funding: This research was funded in part by BioActor BV; the European Union Seventh Framework Programme, grant agreement no. 312090 (BACCHUS); a Grant Top Knowledge Institute, Well on Wheat (www.um-eatwell.nl/wow/).

Conflicts of Interest: Y.S. is an employee of BioActor BV. E.V.R. is supported by the Agency for Innovation by Science and Technology in Flanders. This research received funding from the European Union Seventh Framework Programme (FP7/2007-2013) under grant agreement no. 312090 (BACCHUS). D.J. was in part supported by a Grant Top Knowledge Institute (Well on Wheat). The funders had no role in the design of the manuscript, in the writing of the manuscript, or in the decision to publish the results.

\section{References}

1. Molina-Montes, E.; Sanchez, M.J.; Zamora-Ros, R.; Bueno-de-Mesquita, H.B.; Wark, P.A.; Obon-Santacana, M.; Kuhn, T.; Katzke, V.; Travis, R.C.; Ye, W.; et al. Flavonoid and lignan intake and pancreatic cancer risk in the European prospective investigation into cancer and nutrition cohort. Int. J. Cancer 2016, 139, 1480-1492. [CrossRef]

2. Manach, C.; Scalbert, A.; Morand, C.; Remesy, C.; Jimenez, L. Polyphenols: Food sources and bioavailability. Am. J. Clin. Nutr. 2004, 79, 727-747. [CrossRef]

3. Chanet, A.; Milenkovic, D.; Manach, C.; Mazur, A.; Morand, C. Citrus flavanones: What is their role in cardiovascular protection? J. Agric. Food Chem. 2012, 60, 8809-8822. [CrossRef]

4. Brat, P.; George, S.; Bellamy, A.; Du Chaffaut, L.; Scalbert, A.; Mennen, L.; Arnault, N.; Amiot, M.J. Daily polyphenol intake in France from fruit and vegetables. J. Nutr. 2006, 136, 2368-2373. [CrossRef]

5. Tomas-Barberan, F.A.; Clifford, M.N. Flavanones, chalcones and dihydrochalcones-Nature, occurrence and dietary burden. J. Sci. Food Agric. 2000, 80, 1073-1080. [CrossRef]

6. Gattuso, G.; Barreca, D.; Gargiulli, C.; Leuzzi, U.; Caristi, C. Flavonoid composition of Citrus juices. Molecules 2007, 12, 1641-1673. [CrossRef]

7. Zamora-Ros, R.; Forouhi, N.G.; Sharp, S.J.; Gonzalez, C.A.; Buijsse, B.; Guevara, M.; van der Schouw, Y.T.; Amiano, P.; Boeing, H.; Bredsdorff, L.; et al. The association between dietary flavonoid and lignan intakes and incident type 2 diabetes in European populations: The EPIC-InterAct study. Diabetes Care 2013, 36, 3961-3970. [CrossRef]

8. Cassidy, A.; Rimm, E.B.; O’Reilly, E.J.; Logroscino, G.; Kay, C.; Chiuve, S.E.; Rexrode, K.M. Dietary flavonoids and risk of stroke in women. Stroke 2012, 43, 946-951. [CrossRef]

9. Mink, P.J.; Scrafford, C.G.; Barraj, L.M.; Harnack, L.; Hong, C.P.; Nettleton, J.A.; Jacobs, D.R., Jr. Flavonoid intake and cardiovascular disease mortality: A prospective study in postmenopausal women. Am. J. Clin. Nutr. 2007, 85, 895-909. [CrossRef] 
10. Knekt, P.; Kumpulainen, J.; Jarvinen, R.; Rissanen, H.; Heliovaara, M.; Reunanen, A.; Hakulinen, T.; Aromaa, A. Flavonoid intake and risk of chronic diseases. Am. J. Clin. Nutr. 2002, 76, 560-568. [CrossRef]

11. Goetz, M.E.; Judd, S.E.; Hartman, T.J.; McClellan, W.; Anderson, A.; Vaccarino, V. Flavanone intake is inversely associated with risk of incident ischemic stroke in the REasons for Geographic and Racial Differences in Stroke (REGARDS) study. J. Nutr. 2016, 146, 2233-2243. [CrossRef]

12. Cutler, G.J.; Nettleton, J.A.; Ross, J.A.; Harnack, L.J.; Jacobs, D.R., Jr.; Scrafford, C.G.; Barraj, L.M.; Mink, P.J.; Robien, K. Dietary flavonoid intake and risk of cancer in postmenopausal women: The Iowa Women's Health Study. Int. J. Cancer 2008, 123, 664-671. [CrossRef]

13. Rossi, M.; Garavello, W.; Talamini, R.; La Vecchia, C.; Franceschi, S.; Lagiou, P.; Zambon, P.; Dal Maso, L.; Bosetti, C.; Negri, E. Flavonoids and risk of squamous cell esophageal cancer. Int. J. Cancer 2007, 120, 1560-1564. [CrossRef]

14. Yi, L.Z.; Ma, S.S.; Ren, D.B. Phytochemistry and bioactivity of Citrus flavonoids: A focus on antioxidant, anti-inflammatory, anticancer and cardiovascular protection activities. Phytochem. Rev. 2017, 16, 479-511. [CrossRef]

15. Testai, L.; Calderone, V. Nutraceutical value of citrus flavanones and their implications in cardiovascular disease. Nutrients 2017, 9, 502. [CrossRef]

16. Barreca, D.; Gattuso, G.; Bellocco, E.; Calderaro, A.; Trombetta, D.; Smeriglio, A.; Lagana, G.; Daglia, M.; Meneghini, S.; Nabavi, S.M. Flavanones: Citrus phytochemical with health-promoting properties. Biofactors 2017, 43, 495-506. [CrossRef]

17. Duque, A.L.R.F.; Monteiro, M.; Adorno, M.A.T.; Sakamoto, I.K.; Sivieri, K. An exploratory study on the influence of orange juice on gut microbiota using a dynamic colonic model. Food Res. Int. 2016, 84, 160-169. [CrossRef]

18. Duda-Chodak, A. The inhibitory effect of polyphenols on human gut microbiota. J. Physiol. Pharmacol. 2012, 63, 497-503.

19. Thursby, E.; Juge, N. Introduction to the human gut microbiota. Biochem. J. 2017, 474, 1823-1836. [CrossRef]

20. Wu, H.J.; Wu, E. The role of gut microbiota in immune homeostasis and autoimmunity. Gut Microbes 2012, 3, 4-14. [CrossRef]

21. Belkaid, Y.; Hand, T.W. Role of the microbiota in immunity and inflammation. Cell 2014, 157, $121-141$. [CrossRef] [PubMed]

22. Romier, B.; Schneider, Y.J.; Larondelle, Y.; During, A. Dietary polyphenols can modulate the intestinal inflammatory response. Nutr. Rev. 2009, 67, 363-378. [CrossRef] [PubMed]

23. Tojo, R.; Suarez, A.; Clemente, M.G.; de los Reyes-Gavilan, C.G.; Margolles, A.; Gueimonde, M.; Ruas-Madiedo, P. Intestinal microbiota in health and disease: Role of bifidobacteria in gut homeostasis. World J. Gastroenterol. 2014, 20, 15163-15176. [CrossRef] [PubMed]

24. Tian, T.; Wang, Z.; Zhang, J. Pathomechanisms of oxidative stress in inflammatory bowel disease and potential antioxidant therapies. Oxid. Med. Cell. Longev. 2017, 2017, 4535194. [CrossRef] [PubMed]

25. Mishra, K. Structure activity relationship of antioxidative property of hesperidin. Int. J. Pharm. Erud. 2013, 2, 40-53.

26. Kumar, S.; Pandey, A.K. Chemistry and biological activities of flavonoids: An overview. Sci. World J. 2013, 2013, 162750. [CrossRef] [PubMed]

27. Panche, A.N.; Diwan, A.D.; Chandra, S.R. Flavonoids: An overview. J. Nutr. Sci. 2016, 5, e47. [CrossRef]

28. Porrini, M.; Riso, P. Factors influencing the bioavailability of antioxidants in foods: A critical appraisal. Nutr. Metab. Cardiovasc. Dis. 2008, 18, 647-650. [CrossRef]

29. Manach, C.; Morand, C.; Gil-Izquierdo, A.; Bouteloup-Demange, C.; Remesy, C. Bioavailability in humans of the flavanones hesperidin and narirutin after the ingestion of two doses of orange juice. Eur. J. Clin. Nutr. 2003, 57, 235-242. [CrossRef]

30. Erlund, I.; Meririnne, E.; Alfthan, G.; Aro, A. Plasma kinetics and urinary excretion of the flavanones naringenin and hesperetin in humans after ingestion of orange juice and grapefruit juice. J. Nutr. 2001, 131, 235-241. [CrossRef]

31. Nielsen, I.L.; Chee, W.S.; Poulsen, L.; Offord-Cavin, E.; Rasmussen, S.E.; Frederiksen, H.; Enslen, M.; Barron, D.; Horcajada, M.N.; Williamson, G. Bioavailability is improved by enzymatic modification of the citrus flavonoid hesperidin in humans: A randomized, double-blind, crossover trial. J. Nutr. 2006, 136, 404-408. [CrossRef] 
32. Kanaze, F.I.; Bounartzi, M.I.; Georgarakis, M.; Niopas, I. Pharmacokinetics of the citrus flavanone aglycones hesperetin and naringenin after single oral administration in human subjects. Eur. J. Clin. Nutr. 2007, 61, 472-477. [CrossRef] [PubMed]

33. Braune, A.; Blaut, M. Bacterial species involved in the conversion of dietary flavonoids in the human gut. Gut Microbes 2016, 7, 216-234. [CrossRef] [PubMed]

34. Borges, G.; Lean, M.E.; Roberts, S.A.; Crozier, A. Bioavailability of dietary (poly)phenols: A study with ileostomists to discriminate between absorption in small and large intestine. Food Funct. 2013, 4, 754-762. [CrossRef] [PubMed]

35. Lin, W.; Wang, W.; Yang, H.; Wang, D.; Ling, W. Influence of intestinal microbiota on the catabolism of flavonoids in mice. J. Food Sci. 2016, 81, H3026-H3034. [CrossRef] [PubMed]

36. Kobayashi, S.; Tanabe, S.; Sugiyama, M.; Konishi, Y. Transepithelial transport of hesperetin and hesperidin in intestinal Caco-2 cell monolayers. Biochim. Biophys. Acta 2008, 1778, 33-41. [CrossRef] [PubMed]

37. Pereira-Caro, G.; Borges, G.; Ky, I.; Ribas, A.; Calani, L.; Del Rio, D.; Clifford, M.N.; Roberts, S.A.; Crozier, A. In vitro colonic catabolism of orange juice (poly)phenols. Mol. Nutr. Food Res. 2015, 59, 465-475. [CrossRef]

38. Hervert-Hernandez, D.; Goni, I. Dietary polyphenols and human gut microbiota: A review. Food Rev. Int. 2011, 27, 154-169. [CrossRef]

39. Liu, M.; Zou, W.; Yang, C.; Peng, W.; Su, W. Metabolism and excretion studies of oral administered naringin, a putative antitussive, in rats and dogs. Biopharm. Drug Dispos. 2012, 33, 123-134. [CrossRef]

40. Kim, D.H.; Jung, E.A.; Sohng, I.S.; Han, J.A.; Kim, T.H.; Han, M.J. Intestinal bacterial metabolism of flavonoids and its relation to some biological activities. Arch. Pharm. Res. 1998, 21, 17-23. [CrossRef]

41. Pereira-Caro, G.; Fernandez-Quiros, B.; Ludwig, I.A.; Pradas, I.; Crozier, A.; Moreno-Rojas, J.M. Catabolism of citrus flavanones by the probiotics Bifidobacterium longum and Lactobacillus rhamnosus. Eur. J. Nutr. 2018, 57, 231-242. [CrossRef] [PubMed]

42. Van Rymenant, E.; Salden, B.; Voorspoels, S.; Jacobs, G.; Noten, B.; Pitart, J.; Possemiers, S.; Smagghe, G.; Grootaert, C.; Van Camp, J. A critical evaluation of in vitro hesperidin $2 S$ bioavailability in a model combining luminal (microbial) digestion and Caco-2 cell absorption in comparison to a randomized controlled human trial. Mol. Nutr. Food Res. 2018, 62, e1700881. [CrossRef] [PubMed]

43. Gao, K.; Xu, A.; Krul, C.; Venema, K.; Liu, Y.; Niu, Y.; Lu, J.; Bensoussan, L.; Seeram, N.P.; Heber, D.; et al. Of the major phenolic acids formed during human microbial fermentation of tea, citrus, and soy flavonoid supplements, only 3,4-dihydroxyphenylacetic acid has antiproliferative activity. J. Nutr. 2006, 136, 52-57. [CrossRef] [PubMed]

44. Kay, C.D.; Pereira-Caro, G.; Ludwig, I.A.; Clifford, M.N.; Crozier, A. Anthocyanins and flavanones are more bioavailable than previously perceived: A review of recent evidence. Annu. Rev. Food Sci. Technol. 2017, 8, 155-180. [CrossRef] [PubMed]

45. Chen, T.; Su, W.; Yan, Z.; Wu, H.; Zeng, X.; Peng, W.; Gan, L.; Zhang, Y.; Yao, H. Identification of naringin metabolites mediated by human intestinal microbes with stable isotope-labeling method and UFLC-Q-TOF-MS/MS. J. Pharm. Biomed. Anal. 2018, 161, 262-272. [CrossRef]

46. Zeng, X.; Bai, Y.; Peng, W.; Su, W. Identification of naringin metabolites in human urine and feces. Eur. J. Drug Metab. Pharmacokinet. 2017, 42, 647-656. [CrossRef]

47. Pereira-Caro, G.; Ludwig, I.A.; Polyviou, T.; Malkova, D.; Garcia, A.; Moreno-Rojas, J.M.; Crozier, A. Identification of plasma and urinary metabolites and catabolites derived from orange juice (poly)phenols: Analysis by high-performance liquid chromatography-high-resolution mass spectrometry. J. Agric. Food Chem. 2016, 64, 5724-5735. [CrossRef]

48. Roowi, S.; Mullen, W.; Edwards, C.A.; Crozier, A. Yoghurt impacts on the excretion of phenolic acids derived from colonic breakdown of orange juice flavanones in humans. Mol. Nutr. Food Res. 2009, 53 (Suppl. 1), S68-S75. [CrossRef]

49. Pereira-Caro, G.; Borges, G.; van der Hooft, J.; Clifford, M.N.; Del Rio, D.; Lean, M.E.; Roberts, S.A.; Kellerhals, M.B.; Crozier, A. Orange juice (poly)phenols are highly bioavailable in humans. Am. J. Clin. Nutr. 2014, 100, 1378-1384. [CrossRef]

50. Schar, M.Y.; Curtis, P.J.; Hazim, S.; Ostertag, L.M.; Kay, C.D.; Potter, J.F.; Cassidy, A. Orange juice-derived flavanone and phenolic metabolites do not acutely affect cardiovascular risk biomarkers: A randomized, placebo-controlled, crossover trial in men at moderate risk of cardiovascular disease. Am. J. Clin. Nutr. 2015, 101, 931-938. [CrossRef] 
51. Vallejo, F.; Larrosa, M.; Escudero, E.; Zafrilla, M.P.; Cerda, B.; Boza, J.; Garcia-Conesa, M.T.; Espin, J.C.; Tomas-Barberan, F.A. Concentration and solubility of flavanones in orange beverages affect their bioavailability in humans. J. Agric. Food Chem. 2010, 58, 6516-6524. [CrossRef] [PubMed]

52. Lozupone, C.A.; Stombaugh, J.I.; Gordon, J.I.; Jansson, J.K.; Knight, R. Diversity, stability and resilience of the human gut microbiota. Nature 2012, 489, 220-230. [CrossRef] [PubMed]

53. Rios-Covian, D.; Ruas-Madiedo, P.; Margolles, A.; Gueimonde, M.; de Los Reyes-Gavilan, C.G.; Salazar, N. Intestinal short chain fatty acids and their link with diet and human health. Front. Microbiol. 2016, 7, 185. [CrossRef] [PubMed]

54. van der Beek, C.M.; Dejong, C.H.C.; Troost, F.J.; Masclee, A.A.M.; Lenaerts, K. Role of short-chain fatty acids in colonic inflammation, carcinogenesis, and mucosal protection and healing. Nutr. Rev. 2017, 75, 286-305. [CrossRef] [PubMed]

55. Parkar, S.G.; Stevenson, D.E.; Skinner, M.A. The potential influence of fruit polyphenols on colonic microflora and human gut health. Int. J. Food Microbiol. 2008, 124, 295-298. [CrossRef] [PubMed]

56. Bakar, N.S.; Zin, N.M.; Basri, D.F. Synergy of flavone with vancomycin and oxacillin against vancomycin-intermediate Staphyloccus aureus. Pak. J. Pharm. Sci. 2012, 25, 633-638.

57. Abuelsaad, A.S.; Mohamed, I.; Allam, G.; Al-Solumani, A.A. Antimicrobial and immunomodulating activities of hesperidin and ellagic acid against diarrheic Aeromonas hydrophila in a murine model. Life Sci. 2013, 93, 714-722. [CrossRef]

58. Celiz, G.; Daz, M.; Audisio, M.C. Antibacterial activity of naringin derivatives against pathogenic strains. J. Appl. Microbiol. 2011, 111, 731-738. [CrossRef]

59. Basile, A.; Sorbo, S.; Giordano, S.; Ricciardi, L.; Ferrara, S.; Montesano, D.; Castaldo Cobianchi, R.; Vuotto, M.L.; Ferrara, L. Antibacterial and allelopathic activity of extract from Castanea sativa leaves. Fitoterapia 2000, 71 (Suppl. 1), S110-S116. [CrossRef]

60. Gwiazdowska, D.; Jus, K.; Jasnowska-Malecka, J.; Kluczynska, K. The impact of polyphenols on Bifidobacterium growth. Acta Biochim. Pol. 2015, 62, 895-901. [CrossRef]

61. Cueva, C.; Moreno-Arribas, M.V.; Martin-Alvarez, P.J.; Bills, G.; Vicente, M.F.; Basilio, A.; Rivas, C.L.; Requena, T.; Rodriguez, J.M.; Bartolome, B. Antimicrobial activity of phenolic acids against commensal, probiotic and pathogenic bacteria. Res. Microbiol. 2010, 161, 372-382. [CrossRef] [PubMed]

62. Kabir, F.; Katayama, S.; Tanji, N.; Nakamura, S. Antimicrobial Effects of Chlorogenic Acid and Related Compounds. J. Korean Soc. Appl. Biol. Chem. 2014, 57, 359-365. [CrossRef]

63. Lee, H.C.; Jenner, A.M.; Low, C.S.; Lee, Y.K. Effect of tea phenolics and their aromatic fecal bacterial metabolites on intestinal microbiota. Res. Microbiol. 2006, 157, 876-884. [CrossRef] [PubMed]

64. Barcenilla, A.; Pryde, S.E.; Martin, J.C.; Duncan, S.H.; Stewart, C.S.; Henderson, C.; Flint, H.J. Phylogenetic relationships of butyrate-producing bacteria from the human gut. Appl. Environ. Microbiol. 2000, 66, 1654-1661. [CrossRef] [PubMed]

65. Mao, S.; Zhu, W. Effects of six flavonoid compounds addition on short-chain fatty acids production and human fecal microbial community change during in vitro fermentation. Afr. J. Microbiol. Res. 2011, 5, 4484-4491. [CrossRef]

66. Unno, T.; Hisada, T.; Takahashi, S. Hesperetin modifies the composition of fecal microbiota and increases cecal levels of short-chain fatty acids in rats. J. Agric. Food Chem. 2015, 63, 7952-7957. [CrossRef] [PubMed]

67. Estruel-Amades, S.; Massot-Cladera, M.; Perez-Cano, F.J.; Franch, A.; Castell, M.; Camps-Bossacoma, M. Hesperidin effects on gut microbiota and gut-associated lymphoid tissue in healthy rats. Nutrients 2019, 11, 324. [CrossRef]

68. Salden, B.N.; Troost, F.J.; Possemiers, S.; Stevens, Y.; Masclee, A.A. Maastricht University: Maastricht, The Netherlands, Unpublished work. 2019.

69. Lima, A.C.D.; Cecatti, C.; Fidelix, M.P.; Adorno, M.A.T.; Sakamoto, I.K.; Cesar, T.B.; Sivieri, K. Effect of daily consumption of orange juice on the levels of blood glucose, lipids, and gut microbiota metabolites: Controlled clinical trials. J. Med. Food 2019, 22, 202-210. [CrossRef]

70. Brasili, E.; Hassimotto, N.M.A.; Del Chierico, F.; Marini, F.; Quagliariello, A.; Sciubba, F.; Miccheli, A.; Putignani, L.; Lajolo, F. Daily consumption of orange juice from Citrus sinensis L. Osbeck cv. Cara Cara and cv. Bahia differently affects gut microbiota profiling as unveiled by an integrated meta-omics approach. J. Agric. Food Chem. 2019, 67, 1381-1391. [CrossRef]

71. Bischoff, S.C. 'Gut health': A new objective in medicine? BMC Med. 2011, 9, 24. [CrossRef] 
72. Vancamelbeke, M.; Vermeire, S. The intestinal barrier: A fundamental role in health and disease. Expert Rev. Gastroenterol. Hepatol. 2017, 11, 821-834. [CrossRef] [PubMed]

73. Noda, S.; Tanabe, S.; Suzuki, T. Differential effects of flavonoids on barrier integrity in human intestinal Caco-2 cells. J. Agric. Food Chem. 2012, 60, 4628-4633. [CrossRef] [PubMed]

74. Noda, S.; Tanabe, S.; Suzuki, T. Naringenin enhances intestinal barrier function through the expression and cytoskeletal association of tight junction proteins in Caco-2 cells. Mol. Nutr. Food Res. 2013, 57, 2019-2028. [CrossRef] [PubMed]

75. Fukui, H. Increased intestinal permeability and decreased barrier function: Does it really influence the risk of inflammation? Inflamm. Intest. Dis. 2016, 1, 135-145. [CrossRef] [PubMed]

76. Azuma, T.; Shigeshiro, M.; Kodama, M.; Tanabe, S.; Suzuki, T. Supplemental naringenin prevents intestinal barrier defects and inflammation in colitic mice. J. Nutr. 2013, 143, 827-834. [CrossRef] [PubMed]

77. Shigeshiro, M.; Tanabe, S.; Suzuki, T. Dietary polyphenols modulate intestinal barrier defects and inflammation in a murine model of colitis. J. Funct. Foods 2013, 5, 949-955. [CrossRef]

78. Xu, L.; Yang, Z.L.; Li, P.; Zhou, Y.Q. Modulating effect of Hesperidin on experimental murine colitis induced by dextran sulfate sodium. Phytomedicine 2009, 16, 989-995. [CrossRef]

79. Crespo, M.E.; Galvez, J.; Cruz, T.; Ocete, M.A.; Zarzuelo, A. Anti-inflammatory activity of diosmin and hesperidin in rat colitis induced by TNBS. Planta Med. 1999, 65, 651-653. [CrossRef]

80. Khan, R.A.; Mallick, N.; Feroz, Z. Anti-inflammatory effects of Citrus sinensis L., Citrus paradisi L. and their combinations. Pak. J. Pharm. Sci. 2016, 29, 843-852.

81. Impellizzeri, D.; Bruschetta, G.; Di Paola, R.; Ahmad, A.; Campolo, M.; Cuzzocrea, S.; Esposito, E.; Navarra, M. The anti-inflammatory and antioxidant effects of bergamot juice extract (BJe) in an experimental model of inflammatory bowel disease. Clin. Nutr. 2015, 34, 1146-1154. [CrossRef]

82. Kamboh, A.A.; Zhu, W.Y. Individual and combined effects of genistein and hesperidin on immunity and intestinal morphometry in lipopolysacharide-challenged broiler chickens. Poult. Sci. 2014, 93, 2175-2183. [CrossRef] [PubMed]

83. Bergmann, H.; Rogoll, D.; Scheppach, W.; Melcher, R.; Richling, E. The Ussing type chamber model to study the intestinal transport and modulation of specific tight-junction genes using a colonic cell line. Mol. Nutr. Food Res. 2009, 53, 1211-1225. [CrossRef] [PubMed]

84. Larrosa, M.; Luceri, C.; Vivoli, E.; Pagliuca, C.; Lodovici, M.; Moneti, G.; Dolara, P. Polyphenol metabolites from colonic microbiota exert anti-inflammatory activity on different inflammation models. Mol. Nutr. Food Res. 2009, 53, 1044-1054. [CrossRef] [PubMed]

85. He, S.; Liu, F.; Xu, L.; Yin, P.; Li, D.; Mei, C.; Jiang, L.; Ma, Y.; Xu, J. Protective Effects of Ferulic Acid against Heat Stress-Induced Intestinal Epithelial Barrier Dysfunction In Vitro and In Vivo. PLoS ONE 2016, 11, e0145236. [CrossRef] [PubMed]

86. Aura, A.M. Microbial metabolism of dietary phenolic compounds in the colon. Phytochem. Rev. 2008, 7, 407-429. [CrossRef]

87. Brett, G.M.; Hollands, W.; Needs, P.W.; Teucher, B.; Dainty, J.R.; Davis, B.D.; Brodbelt, J.S.; Kroon, P.A. Absorption, metabolism and excretion of flavanones from single portions of orange fruit and juice and effects of anthropometric variables and contraceptive pill use on flavanone excretion. Br. J. Nutr. 2009, 101, 664-675. [CrossRef] [PubMed]

(C) 2019 by the authors. Licensee MDPI, Basel, Switzerland. This article is an open access article distributed under the terms and conditions of the Creative Commons Attribution (CC BY) license (http://creativecommons.org/licenses/by/4.0/). 